University of Nebraska - Lincoln

DigitalCommons@University of Nebraska - Lincoln

$1-28-2003$

\title{
Pichia pastoris fermentation with mixed-feeds of glycerol and methanol: growth kinetics and production improvement
}

Wenhui Zhang

Karen J. Hywood Potter

Bradley A. Plantz

Vicki L. Schlegel

University of Nebraska-Lincoln, vschlegel3@unl.edu

Leonard A. Smith

See next page for additional authors

Follow this and additional works at: https://digitalcommons.unl.edu/chemengbiochemeng

Part of the Biochemical and Biomolecular Engineering Commons

Zhang, Wenhui; Hywood Potter, Karen J.; Plantz, Bradley A.; Schlegel, Vicki L.; Smith, Leonard A.; and Meagher, Michael M., "Pichia pastoris fermentation with mixed-feeds of glycerol and methanol: growth kinetics and production improvement" (2003). Papers in Biochemical Engineering. 13.

https://digitalcommons.unl.edu/chemengbiochemeng/13

This Article is brought to you for free and open access by the Chemical and Biomolecular Engineering Research and Publications at DigitalCommons@University of Nebraska - Lincoln. It has been accepted for inclusion in Papers in Biochemical Engineering by an authorized administrator of DigitalCommons@University of Nebraska - Lincoln. 
Authors

Wenhui Zhang, Karen J. Hywood Potter, Bradley A. Plantz, Vicki L. Schlegel, Leonard A. Smith, and Michael M. Meagher 
Wenhui Zhang · Karen J. Hywood Potter

Bradley A. Plantz · Vicki L. Schlegel

Leonard A. Smith · Michael M. Meagher

\section{Pichia pastoris fermentation with mixed-feeds of glycerol and methanol: growth kinetics and production improvement}

Received: 20 September 2002/ Accepted: 28 January 2003/Published online: 2 April 2003

(c) Society for Industrial Microbiology 2003

\begin{abstract}
Fed-batch fermentation of a methanol utilization plus $\left(\mathrm{Mut}^{+}\right)$Pichia pastoris strain typically has a growth phase followed by a production phase (induction phase). In the growth phase glycerol is usually used as carbon for cell growth while in the production phase methanol serves as both inducer and carbon source for recombinant protein expression. Some researchers employed a mixed glycerol-methanol feeding strategy during the induction phase to improve production, but growth kinetics on glycerol and methanol and the interaction between them were not reported. The objective of this paper is to optimize the mixed feeding strategy based on growth kinetic studies using a Mut ${ }^{+}$ Pichia strain, which expresses the heavy-chain fragment $\mathrm{C}$ of botulinum neurotoxin serotype $\mathrm{C}$ [BoNT/C $(\mathrm{Hc})]$ intracellularly, as a model system. Growth models on glycerol and methanol that describe the relationship between specific growth rate $(\mu)$ and specific glycerol/ methanol consumption rate $\left(v_{\text {gly }}, v_{\mathrm{MeOH}}\right)$ were established. A mixed feeding strategy with desired $\mu_{\mathrm{gly}} /$ $\mu_{\mathrm{MeOH}}=1,2,3,4\left(\right.$ desired $\mu_{\mathrm{MeOH}}$ set at $\left.0.015 \mathrm{~h}^{-1}\right)$ was employed to study growth interactions and their effect on production. The results show that the optimal desired $\mu_{\mathrm{gly}} / \mu_{\mathrm{MeOH}}$ is around 2 for obtaining the highest BoNT/C $(\mathrm{Hc})$ protein content in cells: about $3 \mathrm{mg} / \mathrm{g}$ wet cells.
\end{abstract}

W. Zhang $(\bowtie) \cdot$ K. J. Hywood Potter · B. A. Plantz

M. M. Meagher

Department of Chemical Engineering,

University of Nebraska-Lincoln, 207M Othmer Hall,

Lincoln, NE 68583-0919, USA

E-mail: wzhang1@unl.edu

Tel.: + 1-402-4729301

Fax: + 1-402-4726989

V. L. Schlegel

Department of Food Science and Technology,

University of Nebraska, Lincoln, NE 68588, USA

L. A. Smith

United States Army Medical Research Institute of Infectious Diseases, Frederick, MD 21702, USA
Keywords Pichia pastoris · Fed-batch fermentation · Mixed feed · Growth model $\cdot$ Botulinum neurotoxin

\section{Introduction}

In the genome of the methylotrophic yeast Pichia pastoris, there are two copies of the alcohol oxidase (AOX) gene, designated $A O X 1$ and $A O X 2$. These genes enable the cells to assimilate methanol as their sole carbon and energy source. The $A O X 1$ promoter regulates $85 \%$ of AOX production while the $A O X 2$ promoter is less active [9]. Pichia expression systems use the $A O X 1$ promoter to drive heterologous protein expression with methanol as the inducer. Through gene disruption [7], the " $A O X 1$ promoter-interesting gene" expression cassette is inserted in the genome $[9,10,16]$. Depending on the locus of insertion, two different phenotypes of Pichia are generated: methanol utilization plus $\left(\mathrm{Mut}^{+}\right)$or methanol utilization slow $\left(\mathrm{Mut}^{\mathrm{s}}\right)$. The former contains both $A O X 1$ and $A O X 2$, the latter only $A O X 2$. For $\mathrm{Mut}^{\mathrm{s}}$ strains, due to their slow utilization of methanol, a mixed feed of glycerol and methanol is commonly employed in the fermentation induction phase; glycerol functions as an efficient substrate for cell growth and target protein production while methanol functions as an inducer. With this strategy, various proteins have been successfully expressed in either fed-batch or continuous operation mode by $\mathrm{Mut}^{\mathrm{s}}$ strains $[1,2,14,19]$. In all of these studies, the optimization of mixed feeding strategy was based on arbitrary ratios of the two substrates in the feed solution. Growth kinetics on glycerol and methanol, and the interaction between them were not studied.

For $\mathrm{Mut}^{+}$strains of Pichia, due to efficient utilization of methanol, a typical fed-batch fermentation strategy is to feed methanol alone as both inducer and carbon and energy source in the induction phase. We developed an exponential feeding strategy based on a growth model describing the relationship between 
specific growth rate $(\mu)$ and specific methanol consumption rate $\left(v_{\mathrm{MeOH}}\right)$ [23]. This makes it possible to maximize production based on an optimal $\mu$. A basic protocol book, "Pichia fermentation process guidelines", which provides a methanol feeding strategy with stepwise changing feed rate, is also available from Invitrogen (San Diego, Calif.).

Mixed feeding strategies in $\mathrm{Mut}^{+}$Pichia fermentations similar to those for $\mathrm{Mut}^{\mathrm{s}}$ strains have been reported. Katakura et al. [13] determined that product formation was dramatically improved by simultaneously feeding glycerol at a rate of $5 \mathrm{ml} \mathrm{l}^{-1} \mathrm{~h}^{-1}$ while maintaining $0.55 \%(\mathrm{v} / \mathrm{v})$ residual methanol in the induction phase. McGrew et al. [15] employed mixed feeds at a glycerol:methanol ratio of $1: 1$ and approximately doubled growth and CD40 ligand expression levels compared to feeding methanol alone. In contrast, Hellwig et al. [12] found that, while maintaining a $0.5 \%$ methanol concentration in the induction phase, supplementary feeding of glycerol strongly inhibited production of an $\mathrm{scFv}$ antibody fragment, and expression was almost completely inhibited when the specific glycerol feed rate $\left(F_{\text {gly }}\right)$ was higher than $6 \mathrm{mg} \mathrm{mg}$-wet cell weight $(\mathrm{WCW})^{-1} \mathrm{~h}^{-1}$. Even at $F_{\text {gly }}$ below $6 \mathrm{mg} \mathrm{mg-}$ $\mathrm{WCW}^{-1} \mathrm{~h}^{-1}$, the expression level was only half that found in the fermentation with methanol feed alone. These attempts at running a mixed feeding strategy in $\mathrm{Mut}^{+}$Pichia fermentations did not further investigate the interaction of cell growth on the two substrates. The objective of this paper is to study mixed feeding strategies based on cell growth kinetics to determine the potential of improving product formation. We used a GS115 $\mathrm{Mut}^{+}$Pichia strain that intracellularly expresses the heavy-chain fragment $\mathrm{C}$ of botulinum neurotoxin serotype $\mathrm{C}[\mathrm{BoNT} / \mathrm{C}(\mathrm{Hc})]$ as a model system. When growing on methanol, the $\mathrm{BoNT} / \mathrm{C}(\mathrm{Hc})$ strain showed a maximum specific growth rate $\left(\mu_{\mathrm{m}}\right)$ of around $0.02 \mathrm{~h}^{-1}$ (as shown later), distinguishing it from a value $0.07 \mathrm{~h}^{-1}$ obtained for another Mut ${ }^{+}$Pichia strain expressing a similar protein, BoNT/A(Hc) [23] and a Mut strain we measured at $0.008 \mathrm{~h}^{-1}$ (data not shown). Therefore, choosing a BoNT $/ \mathrm{C}(\mathrm{Hc})$ strain for this study could be representative for both $\mathrm{Mut}^{\mathrm{s}}$ and $\mathrm{Mut}^{+}$Pichia expression systems. The strain was constructed at the United States Army Medical Research Institute of Infectious Diseases (USAMRIID). BoNT/C $(\mathrm{Hc})$ is one of the seven BoNT(Hc) serotypes, designated A-G, corresponding to seven different strains of Clostridium botulinum. The recombinant BoNT(Hc) are nontoxic $50 \mathrm{kDa}$ fragments that elicit significant protective immunity in mice and are candidate vaccines against botulinum neurotoxin $[3,5]$.

\section{Materials and methods}

\section{Fermentation conditions}

A 1-1 shake flask with $300 \mathrm{ml}$ buffered minimal glycerol yeast extract medium (BMGY, containing $1 \%$ yeast extract, $2 \%$ peptone, $1.34 \%$ yeast nitrogen base, $4 \times 10^{-5} \%$ biotin, $1 \%$ glycerol, $100 \mathrm{mM}$ potassium phosphate, $\mathrm{pH}$ 6.0) was inoculated with $1 \mathrm{ml}$ stock seed. The cultivation lasted for $20-24 \mathrm{~h}$ at $30^{\circ} \mathrm{C}$ and $300 \mathrm{rpm}$ to reach an optical density (at $600 \mathrm{~nm}$ ) of $10-20$. The entire $300 \mathrm{ml}$ propagated culture was used to inoculate a 5-1 fermentor (New Brunswick Scientific, Edison, N.J.) containing 21 basal salts medium (BSM) and $8.7 \mathrm{ml} \mathrm{PTM}_{1}$ trace salts. One liter BSM consists of $26.7 \mathrm{ml}$ $85 \% \mathrm{H}_{3} \mathrm{PO}_{4}, 0.93 \mathrm{~g} \mathrm{CaSO}_{4}, 18.2 \mathrm{~g} \mathrm{~K}_{2} \mathrm{SO}_{4}, 14.9 \mathrm{~g} \mathrm{MgSO}_{4} \cdot 7 \mathrm{H}_{2} \mathrm{O}$, $4.13 \mathrm{~g} \mathrm{KOH}$, and $40.0 \mathrm{~g}$ glycerol. One liter $\mathrm{PTM}_{1}$ (filter-sterilized) consists of $6.0 \mathrm{~g} \mathrm{CuSO}_{4} \cdot 5 \mathrm{H}_{2} \mathrm{O}, 0.08 \mathrm{~g} \mathrm{NaI}, 3.0 \mathrm{~g} \mathrm{MnSO}_{4} \cdot \mathrm{H}_{2} \mathrm{O}, 0.2 \mathrm{~g}$ $\mathrm{Na}_{2} \mathrm{MoO}_{4} \cdot 2 \mathrm{H}_{2} \mathrm{O}, 0.02 \mathrm{~g} \mathrm{H}_{3} \mathrm{BO}_{3}, 0.5 \mathrm{~g} \mathrm{CoCl}_{2}, 20.0 \mathrm{~g} \mathrm{ZnCl}_{2}, 65.0 \mathrm{~g}$ $\mathrm{FeSO}_{4} \cdot 7 \mathrm{H}_{2} \mathrm{O}, 0.2 \mathrm{~g}$ biotin and $5.0 \mathrm{ml} \mathrm{H}_{2} \mathrm{SO}_{4}$. The fermentation was run in fed-batch mode at $30^{\circ} \mathrm{C}$, and $\mathrm{pH}$ was maintained at 5.0 using undiluted $(28 \%)$ ammonium hydroxide. Dissolved oxygen (DO) was maintained above $20 \%$ saturation by adjusting agitation rate and pure oxygen supply.

When the initial glycerol $(40 \mathrm{~g} / \mathrm{l})$ in batch phase was depleted, as indicated by an abrupt increase in DO reading, a $63 \%(\mathrm{w} / \mathrm{v})$ glycerol solution containing $1.2 \%(\mathrm{v} / \mathrm{v}) \mathrm{PTM}_{1}$ was fed at a feed rate of $12 \mathrm{ml} \mathrm{h}^{-1} 1$-broth ${ }^{-1}$ for $1 \mathrm{~h}$ (growth was limited by the feed rate and no glycerol accumulation occurred). Methanol (4 ml) was then injected into the fermentor and, simultaneously, the glycerol feed rate was programmed to decrease linearly from $12 \mathrm{ml} \mathrm{h}^{-1} 1^{-1}$ to 0 over a period of $3 \mathrm{~h}$. This 3 -h period was considered a transition phase that is important for cells to adapt to the methanol efficiently and completely [23]. Following the transition phase, the production phase started, in which $100 \%$ methanol containing $1.2 \%(\mathrm{v} / \mathrm{v}) \mathrm{PTM}_{1}$ and $0.05 \%(\mathrm{w} / \mathrm{v})$ antifoam (KFO 673, KABO Chemicals, Cheyenne, Wyo.) was fed under control of a methanol sensor (MC-168 Methanol Monitor and Controller, PTI Instruments, Kathleen, Ga.; the sensing material in the MC-168 is TGS822 alcohol sensor from Figaro USA, Glenview, Ill.), or at a programmed feed rate based on a desired growth rate. Five or six time-course samples, taken every 4-6 h, were removed during the production phase.

To determine the growth model on a glycerol phase, a $63 \%$ $(\mathrm{w} / \mathrm{v})$ glycerol solution containing $1.2 \%(\mathrm{v} / \mathrm{v}) \mathrm{PTM}_{1}$ was fed at a programmed feed rate based on a desired growth rate (glycerol feeding strategy as shown later), after the initial glycerol batch phase. Four to six time-course samples, taken every $3-5 \mathrm{~h}$, were removed during the glycerol fed-batch phase.

\section{Cell density measurement}

Cell density was expressed as grams WCW per liter broth, which was obtained by centrifuging the samples at 2,000 $\mathrm{g}$ for $10 \mathrm{~min}$. All kinetic calculations were based on WCW. The methanol concentration in samples was measured by gas chromatography (GC-17A, Shimadzu, Columbia, Md.) with isopropyl alcohol as an internal standard.

\section{$\mathrm{BoNT} / \mathrm{C}(\mathrm{Hc})$ analysis}

BoNT/C(Hc) protein was released from cells through bead breaking, and quantified by western blot analysis. Cell paste samples of $0.2-0.5 \mathrm{~g}$ were suspended in $10 \mathrm{ml}$ washing buffer $(145 \mathrm{mM} \mathrm{NaCl}$, $31.5 \mathrm{mM}$ sodium acetate, $18.5 \mathrm{mM}$ acetic acid, $\mathrm{pH}$ 5.0), then spun at $2,000 \mathrm{~g}$ for $10 \mathrm{~min}$ to obtain washed cell pellets. The cell pellets were resuspended to a density of $50 \mathrm{~g}-\mathrm{WCW} / 1$ in lysis buffer, which contains $2.5 \mathrm{~g} / 1$ 3-[(3-cholamidopropyl)dimethylammonio]-1-propanesulfonate (CHAPS), $5 \mathrm{mM}$ EDTA, $500 \mathrm{mM} \mathrm{NaCl}, 50 \mathrm{mM}$ $\mathrm{NaH}_{2} \mathrm{PO}_{4}, 1 \mathrm{mM}$ phenylmethanesulfonyl fluoride (PMSF), and $\mathrm{pH}$ adjusted to 7.5. Aliquots $(1 \mathrm{ml})$ of the cell suspension were mixed with approximately $2.2 \mathrm{~g}$ zirconia/silica beads (Biospec, Bartlesville, OK) in $2.0 \mathrm{ml}$ screw cap tubes followed by disruption at $4^{\circ} \mathrm{C}$ with a vibrating disrupter (Mini-BeadBeater-8, Biospec) for eight cycles ( $1 \mathrm{~min}$ vibrating and $4 \mathrm{~min}$ resting/cycle). The lysate/bead mixture was centrifuged until the supernatant was clear.

The acquired supernatant was diluted 3-fold with lysis buffer, and $90 \mu \mathrm{l}$ diluted supernatant was mixed with $30 \mu \mathrm{l} 4 \times$ concentrated Tris-glycerine SDS sample buffer $(252 \mathrm{mM}$ Tris- $\mathrm{HCl}, 40 \%$ glycerol, $8 \%$ SDS, $0.01 \%$ bromophenol blue, $\mathrm{pH} 6.8$ ). The mixture 
was heated at $90^{\circ} \mathrm{C}$ for $5-10 \mathrm{~min}$, then $35-\mu 1$ aliquots were loaded onto a 10-well 4-20\% Tris-glycine SDS-PAGE gel (Novex Pre-Cast gel, Invitrogen, San Diego, Calif.). Each sample was loaded in duplicate. A standard sample containing $703.13 \mathrm{ng}$ BoNT/C(Hc) was loaded on each gel. After running the SDS-PAGE $(150 \mathrm{~V}$, $1.8 \mathrm{~h}$, running buffer: SepraBuff TRIS GLY SDS running buffer, OWL Seperation Systems, Woburn, Mass.), the gel was soaked in a transfer buffer (SepraBuff TRIS GLY running and blotting buffer) for 5-10 $\mathrm{min}$; proteins were then transferred from the gel to a polyvinylidene fluoride (PVDF) membrane (soaked in methanol before use) using a semi-dry transfer cell (Trans-Blot SD, Bio-Rad, Hercules, Calif.; $12 \mathrm{~V}, 1 \mathrm{~h}$ ). Following transfer, the PVDF membrane was soaked in blocker solution $(5 \%$ blotting grade dry milk in $100 \mathrm{ml}$ TBS buffer: $25 \mathrm{mM}$ Tris base, $140 \mathrm{mM} \mathrm{NaCl}, 2.5 \mathrm{mM}$ $\mathrm{KCl}$ ) for $1 \mathrm{~h}$. The membrane was incubated with the primary antibody solution for $16 \mathrm{~h}$, then rinsed $3 \times 10 \mathrm{~min}$ in TBS buffer, and soaked in secondary antibody solution for $2-4 \mathrm{~h}$. The final rinse was $3 \times 10 \mathrm{~min}$ in TBS buffer. Protein on the membrane was visualized by chemiluminescence using ECL + Plus (Lumigen, Southfield, Mich.) with a 5 min incubation (in the dark), followed by exposure of two films (Hyperfilm ECL, Amersham Pharmacia, Piscataway, N.J.) each with a different exposure time (2-5 min). The films were developed (Kodak GBX fixer and developer) to reveal the bands of $\mathrm{BoNT} / \mathrm{C}(\mathrm{Hc})$ protein. Band intensities were obtained by scanning the films (HP ScanJet 6300C scanner) and digitizing the bands (UN-SCAN-IT, Automated Digitizing System, Version 5.1, Silk Scientific Corporation, Orem, Utah). BoNT/ $\mathrm{C}(\mathrm{Hc})$ in each band was quantified from a standard curve that showed the relationship between band intensity and protein amount.

\section{Results and discussion}

Growth kinetics on glycerol

In the batch phase, with an initial glycerol concentration of $40 \mathrm{~g} / 1$, cells were grown without limitation of nutrients. The maximum growth rate on glycerol, $\mu_{\mathrm{gly}, \mathrm{m}}$, and maximum glycerol specific consumption rate, $v_{\mathrm{gly}, \mathrm{m}}$, were determined as $\mu_{\mathrm{gly}, \mathrm{m}}=0.177 \mathrm{~h}^{-1}$ and $v_{\mathrm{gly}, \mathrm{m}}=$ $0.0688 \mathrm{~g} \mathrm{~h}^{-1} \mathrm{~g}-W C W^{-1}$. Knowing $\mu_{\mathrm{gly}, \mathrm{m}}$ and $v_{\mathrm{gly}, \mathrm{m}}$, the glycerol feed rate, $F_{\text {gly }}$, to run a fed-batch process with the desired $\mu_{\mathrm{gly}, \mathrm{d}}\left(\leq \mu_{\mathrm{gly}, \mathrm{m}}\right)$ can be estimated as in [23]:

$F_{\mathrm{gly}}=v_{\mathrm{gly}} \mathrm{X}_{0} \mathrm{~V}_{0} e^{\mu_{\mathrm{gly}, \mathrm{d}} \mathrm{t}}=\frac{\mu_{\mathrm{gly}, \mathrm{d}} v_{\mathrm{gly}, \mathrm{m}} \mathrm{X}_{0} \mathrm{~V}_{0} e^{\mu_{\mathrm{gly}, \mathrm{d}} \mathrm{t}}}{\mu_{\mathrm{gly}, \mathrm{m}}}$

where $\mathrm{X}_{0}$ and $\mathrm{V}_{0}$ are the cell density and broth volume at the beginning of the glycerol fed-batch phase, and the feed time of glycerol. Fed-batch runs with different $\mu_{\mathrm{gly}, \mathrm{d}}$ from 0 to $\mu_{\mathrm{gly}, \mathrm{m}}$ were conducted using the feeding strategy in Eq. 1. The actual $\mu_{\mathrm{gly}}$ (which could differ from $\left.\mu_{\mathrm{gly}, \mathrm{d}}\right)$ and $v_{\mathrm{gly}}$, was determined from each run. The method used to calculate the specific rates (as well as all other kinetics) was referred to in a previous publication [23]. Figure 1 shows the linear dependence of $v_{\mathrm{gly}}$ on $\mu_{\mathrm{gly}}$, and the resulting equation:

$v_{\text {gly }}=0.503 \mu_{\text {gly }}+0.0065$

With the fed-batch growth model in Eq. 2, estimation of $F_{\text {gly }}$ by Eq. 1$)$ was corrected to realize a growth rate approaching $\mu_{\mathrm{gly}, \mathrm{d}}$, namely:

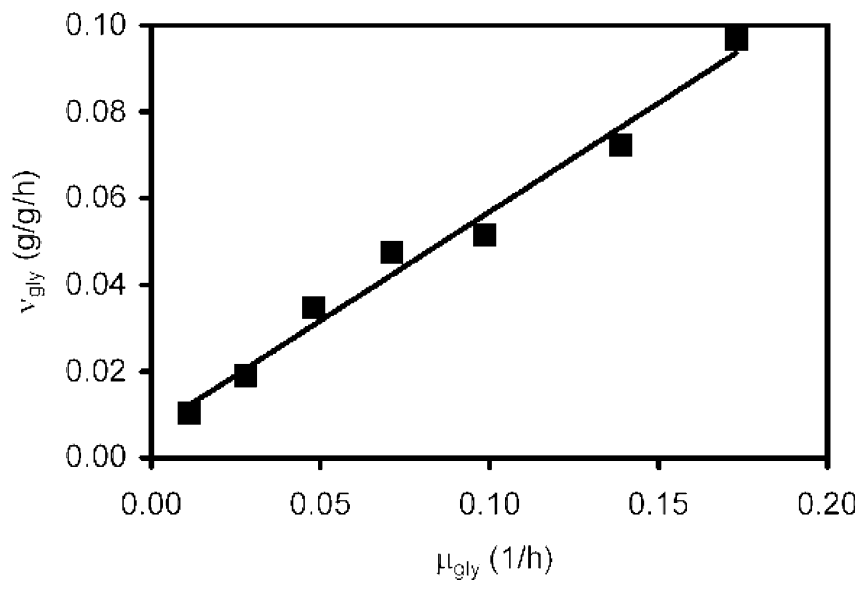

Fig. 1 Dependence of glycerol specific consumption rate $\left(v_{g l y}\right)$ on specific growth rate $\left(\mu_{g l y}\right)$ in glycerol fed-batch growth

$F_{\text {gly }}=\left(0.503 \mu_{\mathrm{gly}, \mathrm{d}}+0.0065\right) \mathrm{X}_{0} \mathrm{~V}_{0} e^{\mu_{\mathrm{gly}, \mathrm{d}} \mathrm{t}}$

As shown later, the feeding strategy of Eq. 3 will be applied to the design of fed-batch fermentations with mixed feeds of glycerol and methanol assuming the coexisting methanol feed has no effects on the kinetics of glycerol consumption.

The catabolic pathway of glycerol in a methylotrophic yeast such as Pichia, involves passive diffusion across the membrane, phosphorylation by a glycerol kinase, and oxidation by a mitochondrial glycerol phosphate ubiquinone oxireductase [11]. Glycerol enters glycolysis after its conversion to glyceraldehyde 3-phosphate, and requires respiration to oxidize NADH in order to serve as an energy source. The glycerol catabolic process is independent of the methanol metabolism pathways described elsewhere [18]. Therefore, although the growth model on glycerol, Eq. 2, was obtained with the BoNT/C(Hc) strain employed in this research, the model can be applied to the design of fedbatch growth on glycerol for all other GS115-derived Pichia clones, whether they are $\mathrm{Mut}^{+}$or Mut .

\section{Growth kinetics on methanol}

P. pastoris cannot tolerate a high methanol concentration in the fermentation due to accumulation of formaldehyde and hydrogen peroxide inside the cells, both of which are oxidized products of methanol by AOX and toxic to the cells $[6,8,21]$. As discovered in our previous work [23], methanol levels above $3.65 \mathrm{~g} / 1$ (calculated from the growth model) start to show growth inhibition. Therefore, unlike growth on glycerol, it is impossible to measure the maximum growth rate $\left(\mu_{\mathrm{MeOH}, \mathrm{m}}\right)$ by growing cells in batch mode with a high methanol level. To reveal the $\mu_{\mathrm{MeOH}, \mathrm{m}}$, as well as the corresponding maximum methanol specific consumption rate $\left(v_{\mathrm{MeOH}, \mathrm{m}}\right)$, we ran the fed-batch fermentation employing a methanol sensor to control methanol feeding to maintain the 
methanol level at 2-4 g/l. A proportional, integral and derivative (PID) control mode was applied for the methanol control system [24]. Figure 2 shows the timecourse of total cell growth (XV) and the methanol level (S) controlled by the sensor. Exponential growth was observed within $50 \mathrm{~h}$ of methanol feeding time. The $\mu_{\mathrm{MeOH}, \mathrm{m}}$ and $v_{\mathrm{MeOH}, \mathrm{m}}$ were $0.02 \mathrm{~h}^{-1}$ and $0.028 \mathrm{~g} \mathrm{~h}^{-1} \mathrm{~g}$ $\mathrm{WCW}^{-1}$, respectively. The $\mu_{\mathrm{MeOH}, \mathrm{m}}$ is much lower than that of a typical Mut ${ }^{+}$Pichia strain, i.e., $0.07 \mathrm{~h}^{-1}$ [24], but higher than a Mut strain, $0.008 \mathrm{~h}^{-1}$ (data not shown). This suggests that methanol metabolism of the BoNT/C(Hc) Pichia strain was affected by either expression of the heterologous protein or the gene insertion event. A similar phenomenon was also observed in an Escherichia coli expression system in which a recombinant protein changed host strain bioactivities [22].

Based on the obtained $\mu_{\mathrm{MeOH}, \mathrm{m}}$ and $v_{\mathrm{MeOH}, \mathrm{m}}$, we conducted fed-batch fermentations with different desired growth rates, $\mu_{\mathrm{MeOH}, \mathrm{d}}\left(\leq \mu_{\mathrm{MeOH}, \mathrm{m}}\right)$, by feeding methanol at a feed rate, $F_{\mathrm{MeOH}}$, estimated as in [23]:

$$
\begin{aligned}
F_{\mathrm{MeOH}} & =v_{\mathrm{MeOH}} \mathrm{X}_{0} \mathrm{~V}_{0} e^{\mu_{\mathrm{MeOH}, \mathrm{d}} \mathrm{t}} \\
& =\frac{\mu_{\mathrm{MeOH}, \mathrm{d}} v_{\mathrm{MeOH}, \mathrm{m}} \mathrm{X}_{0} \mathrm{~V}_{0} e^{\mu_{\mathrm{MeOH}, \mathrm{d}} \mathrm{t}}}{\mu_{\mathrm{MeOH}, \mathrm{m}}}
\end{aligned}
$$

where $\mathrm{X}_{0}$ and $\mathrm{V}_{0}$ are the cell density and broth volume at the beginning of the methanol fed-batch phase, and the feed time of methanol. Similar to the limited fed-batch growth on glycerol, an actual $\mu_{\mathrm{MeOH}}$ and $v_{\mathrm{MeOH}}$ were obtained from each run, and the linear dependence of $v_{\mathrm{MeOH}}$ on $\mu_{\mathrm{MeOH}}$ is shown in Fig. 3. The linear relationships are expressed as:

$v_{\mathrm{MeOH}}=0.766 \mu_{\mathrm{MeOH}}+0.0128$

Equation 5 includes the maintenance coefficient, $0.0128 \mathrm{~g}-\mathrm{MeOH} \mathrm{h}^{-1} \mathrm{~g}-\mathrm{WCW}^{-1}$, and was substituted into Eq. 4, to give Eq. 6:

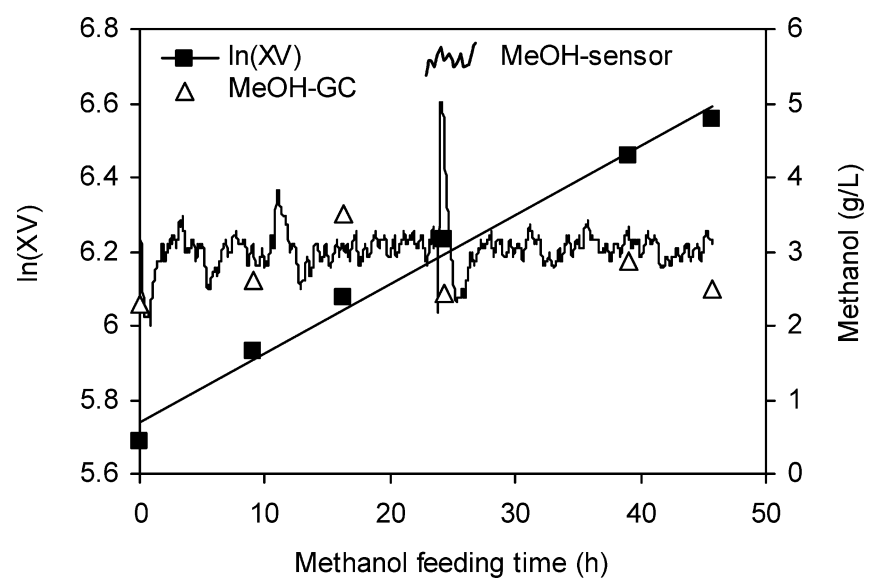

Fig. 2 Time-course of total grown cells and controlled methanol level in the methanol fed-batch phase. $\mathrm{MeOH}$-sensor Methanol online read value from the methanol sensor, $\mathrm{MeOH}-G \mathrm{C}$ methanol concentration in the samples analyzed by gas chromatography
$F_{\mathrm{MeOH}}=\left(0.766 \mu_{\mathrm{MeOH}, \mathrm{d}}+0.0128\right) \mathrm{X}_{0} \mathrm{~V}_{0} e^{\mu_{\mathrm{MeOH}, \mathrm{d}} \mathrm{t}}$

Mixed feed and production improvement

The BoNT/C $(\mathrm{Hc})$ content in the cells $(\alpha)$ reached a maximum after $10 \mathrm{~h}$ of methanol feeding, and remained constant during the remainder of the exponential growth phase, similar to the intracellular production of BoNT/ $\mathrm{A}(\mathrm{Hc})$ [23]. The average $\alpha$ during the stable period (defined as quasi-steady state) represented the production level at a corresponding $\mu_{\mathrm{MeOH}}$. The effect of $\mu_{\mathrm{MeOH}}$ on $\alpha$ using only methanol during fed-batch fermentation is presented in Fig. 4. The optimum $\mu_{\mathrm{MeOH}}$ was $0.015 \mathrm{~h}^{-1}$ and achieved $\alpha=2 \mathrm{mg} / \mathrm{g}$. This is similar to that observed for $\mathrm{BoNT} / \mathrm{A}(\mathrm{Hc})$ production [23] in which the optimal $\mu_{\mathrm{MeOH}}$ was $0.0267 \mathrm{~h}^{-1}$ rather than the $\mu_{\mathrm{MeOH}, \mathrm{m}}$ $\left(0.0709 \mathrm{~h}^{-1}\right)$.

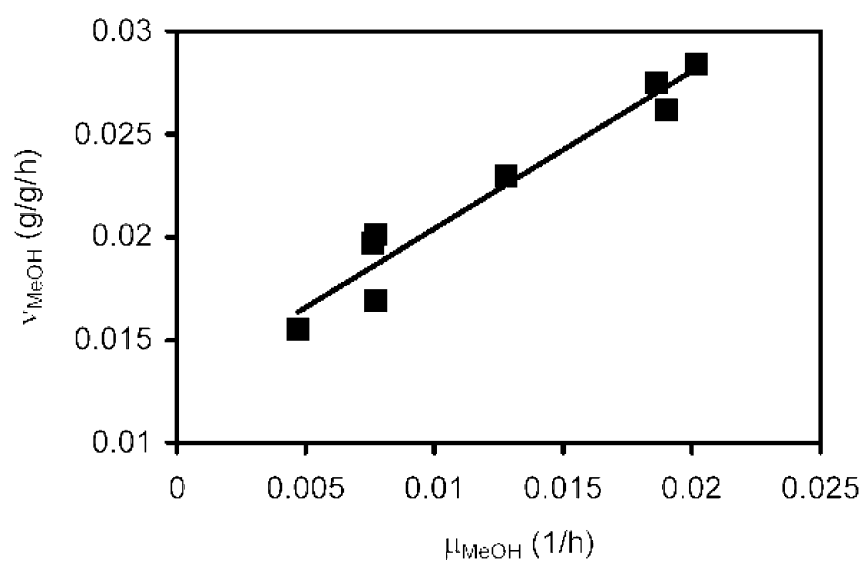

Fig. 3 Dependence of methanol specific consumption rates $\left(v_{\mathrm{MeOH}}\right)$ on specific growth rate $\left(\mu_{\mathrm{MeOH}}\right)$ in methanol fed-batch growth

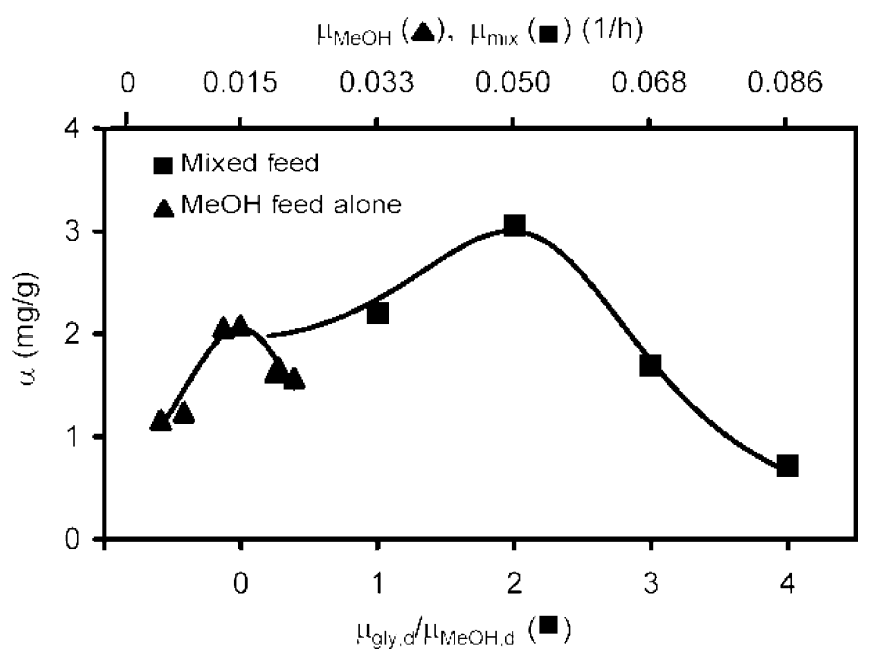

Fig. 4 Heavy-chain fragment $\mathrm{C}$ of botulinum neurotoxin serotype $\mathrm{C}[\mathrm{BoNT} / \mathrm{C}(\mathrm{Hc})]$ content in cells $(\alpha)$ under methanol feed alone and mixed feed 
The detailed mechanism explaining why $\mu$ affects $\alpha$ remains unknown, but the imbalance of energy supply for growth and production is believed to be one of the reasons $[4,17]$. Based on this supposition, and considering the slow methanol assimilation in this strain, we proposed a mixed feeding strategy, namely, feeding glycerol simultaneously in the methanol fed-batch phase, to explore the potential for improving production. As we discussed, the mixed feeding strategy is generally employed for $\mathrm{Mut}^{\mathrm{s}}$ Pichia fermentations in view of their slow utilization of methanol, and has also been applied in $\mathrm{Mut}^{+}$strains by several researchers. However, all these studies relied on arbitrary combinations of the two substrates (glycerol and methanol) for optimizing the mixed feed design. Here we investigated the strategy based on the growth kinetics. Specifically, we optimized the growth rate ratio of $\mu_{\mathrm{gly}}: \mu_{\mathrm{MeOH}}$ rather than the quantity ratio of glycerol:methanol in the mixed feed. $\mu_{\mathrm{gly}}$ and $\mu_{\mathrm{MeOH}}$ are the growth rate contributed by glycerol and methanol, respectively, and the total growth rate on a mixed feed, $\mu_{\text {mix }}$, expressed as:

$\mu_{\mathrm{mix}}=\mu_{\mathrm{gly}}+\mu_{\mathrm{MeOH}}$

We ran a mixed feeding strategy with desired $\mu_{\mathrm{gly}}: \mu_{\mathrm{MeOH}}=1,2,3,4$ to study the growth interaction of the two substrates and its effect on production. With growth on methanol feed alone, $\mu_{\mathrm{MeOH}}=0.015 \mathrm{~h}^{-1}$ was the optimal growth rate for maximum $\alpha$. Accordingly, we fixed the desired growth rate on methanol $\left(\mu_{\mathrm{MeOH}, \mathrm{d}}\right)$ at $0.015 \mathrm{~h}^{-1}$ while varying the desired growth rate on glycerol $\left(\mu_{\mathrm{gly}, \mathrm{d}}\right)$ for the mixed feed design. Based on Eqs. 3 and 6, the glycerol and methanol feed rate were given as:

$F_{\text {gly }}=\left(0.503 \mu_{\text {gly }, \mathrm{d}}+0.0065\right) \mathrm{X}_{0} \mathrm{~V}_{0} e^{\mu_{\text {mix }, \mathrm{d}}}{ }^{\mathrm{t}}$

$F_{\mathrm{MeOH}}=\left(0.766 \mu_{\mathrm{MeOH}, \mathrm{d}}+0.0128\right) \mathrm{X}_{0} \mathrm{~V}_{0} e^{\mu_{\text {mix, } \mathrm{d}}}$

where $\mu_{\text {mix,d }}$ was calculated as $\mu_{\mathrm{MeOH}, \mathrm{d}}+\mu_{\mathrm{gly}, \mathrm{d}}$ according to Eq. 7, and the feed time of glycerol and metha-

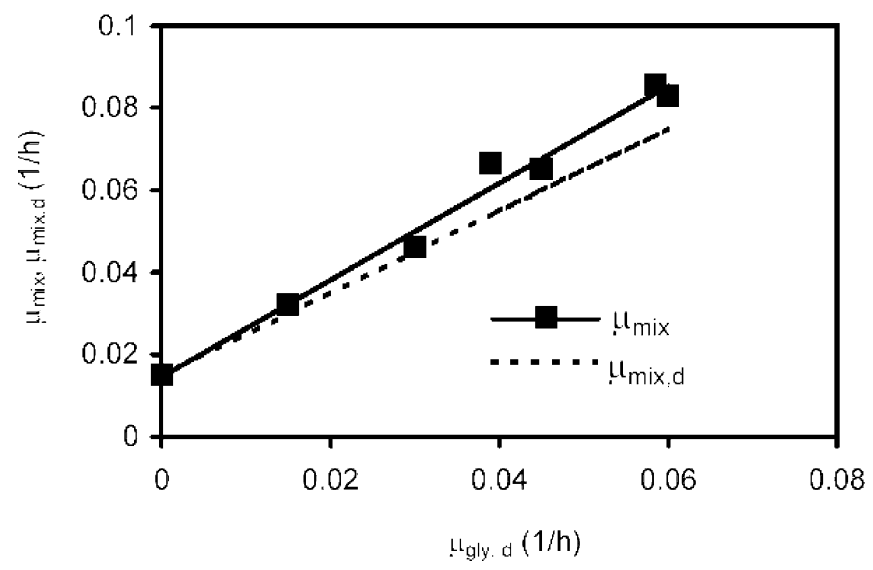

Fig. 5 Actual $\mu_{m i x}$ achieved from the runs with $\mu_{M e O H, d}=$ $0.015 \mathrm{~h}^{-1}$ and various $\mu_{g l y, d} \cdot \mu_{m i x, d}=\mu_{M e O H, d}+\mu_{g l y, d}$ was also plotted as a dotted line nol. Figure 5 shows the actual $\mu_{\text {mix }}$ achieved from the runs performing the feeding strategy of Eqs. 8 and 9 with $\mu_{\mathrm{MeOH}, \mathrm{d}}=0.015 \mathrm{~h}^{-1}$ and various $\mu_{\mathrm{gly}, \mathrm{d}}$. It was found that $\mu_{\text {mix }}$ was slightly higher than $\mu_{\text {mix,d }}$ and had the following relationship with $\mu_{\mathrm{gly}, \mathrm{d}}$ :

$\mu_{\text {mix }}=1.18 \mu_{\mathrm{gly}, \mathrm{d}}+0.015$

Compared with Eq. 7, and noting $\mu_{\mathrm{MeOH}, \mathrm{d}}$ $=0.015 \mathrm{~h}^{-1}$, Eq. 10 shows that the total growth was promoted in the presence of glycerol feeding. It is known that excess glycerol inhibits the $A O X$ promoter [20]. We obtained the opposite result due to the fact that the glycerol feed rate we ran only supported growth below $0.06 \mathrm{~h}^{-1}$, which was far from the maximum $\mu$ on glycerol $\left(0.177 \mathrm{~h}^{-1}\right)$. Thus, we concluded that during growth on a mixed feed with $\mu_{\mathrm{gly}, \mathrm{d}} \leq$ $0.06 \mathrm{~h}$, i.e., $\mu_{\mathrm{gly}, \mathrm{d}}: \mu_{\mathrm{MeOH}, \mathrm{d}} \leq 4$ for this strain, the supplementary feeding of glycerol enhanced the overall growth rather than functioned as a repressor. This observation indicates that running a mixed feed in $\mathrm{Mut}^{+}$Pichia fermentations is feasible without causing growth inhibition by glycerol when the feeding strategy is properly designed. The production level under the mixed feed design can be examined to discover the optimal feeding strategy.

Figure 4 shows the production levels obtained under the mixed feed strategy with various $\mu_{\mathrm{gly}, \mathrm{d}} / \mu_{\mathrm{MeOH}, \mathrm{d}}$ while $\mu_{\mathrm{MeOH}, \mathrm{d}}$ was set to $0.015 \mathrm{~h}^{-1}$, as well as a comparison with methanol feed alone. It was found that $\mu_{\mathrm{gly}, \mathrm{d}} / \mu_{\mathrm{MeOH}, \mathrm{d}}=2$, which corresponded to an obtained $\mu_{\text {mix }}$ of $0.05 \mathrm{~h}^{-1}$, delivered the highest $\alpha$, and the production was not inhibited by the supplementary glycerol feeding until a feeding strategy with $\mu_{\mathrm{gly}, \mathrm{d}} / \mu_{\mathrm{MeOH}, \mathrm{d}}$ $>3$ was run. Substituting the optimal $\mu_{\mathrm{gly}, \mathrm{d}}=0.03 \mathrm{~h}^{-1}$ and $\mu_{\mathrm{MeOH}, \mathrm{d}}=0.015 \mathrm{~h}^{-1}$ into Eqs. 8 and 9, the optimal feed rate ratio of $F_{\mathrm{gly}}: F_{\mathrm{MeOH}}$ was simply derived to be 0.889 . This discovery demonstrated that the mixed feeding strategy based on growth kinetics as in Eqs. 2 and 5 can be optimized to maximize production. The optimal strategy can be applied to any cell densities as a result of the direct association with growth rate instead of the arbitrary combinations of the two substrates that was used in previous researches. Since growth models were developed on both glycerol (Eq. 2) and methanol (Eq. 5), a thorough simulation for the optimal process can be made in the same way as for optimization of $\mathrm{BoNT} / \mathrm{A}(\mathrm{Hc})$ production [23]. It is predicted that the methods developed in this paper can be applied to mixed feed design for both $\mathrm{Mut}^{+}$ and Mut ${ }^{\mathrm{s}}$ Pichia fermentations producing a variety of recombinant proteins.

Acknowledgements We thank UNL undergraduate students Kian Ann Teh and Kok Wah Lim for operating the fermentations, and Michael Dux and Angeline Yong for performing the Western Blot analysis. We also thank Jacqueline D. Andersen and all other members of BPDF-UNL fermentation group for their assistance in running the fermentations. This research was financially supported by the United States Army Medical Research and Materiel Command (contract number: DAMD-17-98-C-8034). 


\section{References}

1. d'Anjou MC, Daugulis AJ (2001) A rational approach to improving productivity in recombinant Pichia pastoris fermentation. Biotechnol Bioeng 72:1-11

2. Brierley RA, Bussineau C, Kosson R, Melton A, Siegel RS (1990) Fermentation development of recombinant Pichia pastoris expressing the heterologous gene: bovine lysozyme. Ann N Y Acad Sci 589:350-362

3. Byrne MP, Smith TJ, Montgomery VA, Smith LA (1998) Purification, potency, and efficacy of the botulinum neurotoxin type A binding domain from Pichia pastoris as a recombinant vaccine candidate. Infect Immunol 66:4817-4822

4. Chim-Anage P, Shioya S, Suga K (1991) Maximum histidine production by fed-batch culture of Brevibacterium flavum. J Ferment Bioeng 71:186-190

5. Clayton MA, Clayton JM, Brown DR, Middlebrook JL (1995) Protective vaccination with a recombinant fragment of Clostridium botulinum neurotoxin serotype A expressed from a synthetic gene in Escherichia coli. Infect Immunol 63:2738-2742

6. Couderc R, Baratti J (1980) Oxidation of methanol by the yeast, Pichia pastoris: purification and properties of the alcohol oxidase. Agric Biol Chem 44:2279-2289

7. Cregg JM, Madden KR (1987) Development of yeast transformation systems and construction of methanol-utilizationdefective mutants of Pichia pastoris by gene disruption. In: Stewart GG (ed) Biological research on industrial yeast, vol II. CRC Press, Boca Raton, Fla., pp 1-18

8. Cregg JM, Madden KR (1988) Development of the methylotrophic yeast, Pichia pastoris, as a host system for the production of foreign proteins. In: Pierce G (ed) Development in industrial microbiology, vol 29. pp 33-41

9. Cregg JM, Madden KR, Barringer KJ, Thill GP, Stillman CA (1989) Functional characterization of the two alcohol oxidase genes from the yeast Pichia pastoris. Mol Cell Biol 9:1316-1323

10. Cregg JM, Cereghino JL, Shi J, Higgins DR (2000) Recombinant protein expression in Pichia pastoris. Mol Biotechnol 16:23-52

11. Gancedo C, Gancedo JM, Sols A (1968) Glycerol metabolism in yeasts: pathways of utilization and production. Eur J Biochem 5:165-172

12. Hellwig S, Emde F, Raven NPG, Henke M, Van der Logt P, Fischer R (2001) Analysis of single-chain antibody production in Pichia pastoris using on-line methanol control in fedbatch and mixed-feed fermentations. Biotechnol Bioeng $74: 344-352$
13. Katakura Y, Zhang W, Zhuang G, Omasa T, Kishimoto M, Goto Y, Suga K-I (1998) Effect of methanol concentration on the production of human beta2-glycoprotein I domain $\mathrm{V}$ by a recombinant Pichia pastoris: a simple system for the control of methanol concentration using a semiconductor gas sensor. J Ferment Bioeng 86:482-487

14. Loewen MC, Liu X, Davies PL, Daugulis AJ (1997) Biosynthetic production of type II fish antifreeze protein: fermentation by Pichia pastoris. Appl Microbiol Biotechnol 48:480-486

15. McGrew JT, Leiske D, Dell B, Klinke R, Krasts D, Wee SF, Abbott N, Armitage R, Harrington K (1997) Expression of trimeric CD40 ligand in Pichia pastoris: use of a rapid method to detect high-level expressing transformants. Gene 187:193200

16. Romanos MA, Scorer CA, Clare JJ (1992) Foreign gene expression in yeast: a review. Yeast 8:423-488

17. Shioya S (1992) Optimization and control in fed-batch bioreactors. In: Fiechter A (ed) Advances in biochemical engineering/biotechnology, vol 46. Springer, Berlin Heidelberg New York, pp 109-142

18. Sibirny AA, Titorenko VI, Gonchar MV, Ubiyvovk VM, Ksheminskaya GP, Vitvitskaya OP (1988) Genetic control of methanol utilization in yeasts. J Basic Microbiol 28:293-319

19. Sreekrishna K, Nelles L, Potenz R, Cruze J, Mazzaferro P, Fish W, Fuke M, Holden K, Phelps D (1989) High-level expression, purification, and characterization of recombinant human tumor necrosis factor synthesized in the methylotrophic yeast Pichia pastoris. Biochemistry 28:4117-4125

20. Tschopp JF, Brust PF, Cregg JM, Stillman CA, Gingeras TR (1987) Expression of the lacZ gene from two methanol-regulated promoters in Pichia pastoris. Nucleic Acids Res 15:38593876

21. Van der Klei IJ, Bystrykh LV, Harder W (1990) Alcohol oxidase from Hansenula polymorpha CBS 4732. Methods Enzymol $188: 420-427$

22. Wong HH, Kim YC, Lee SY, Chang HN (1998) Effect of postinduction nutrient feeding strategies on the production of bioadhesive protein in Escherichia coli. Biotechnol Bioeng 60:271-276

23. Zhang W, Bevins MA, Plantz BA, Smith LA, Meagher MM (2000) Modeling Pichia pastoris growth on methanol and optimizing the production of a recombinant protein, the heavychain fragment $\mathrm{C}$ of botulinum neurotoxin, serotype $\mathrm{A}$. Biotechnol Bioeng 70:1-8

24. Zhang W, Smith LA, Plantz BA, Meagher MM (2002) Design of methanol feed control in Pichia pastoris fermentations based upon a growth model. Biotechnol Prog 18:1392-1399 